\title{
PENGARUH PENAMBAHAN TANAMAN BERUAS LAUT (Scaevola taccada) DALAM PEMBUATAN BIOPLASTIK DARI Kappaphycus alvarezii
}

\author{
The Effect of Adding Beruas Laut's (Scevola teccada) Plant in Creating Bioplastic from \\ Kapaphycus alvarezi \\ Syarifah Norhayati ${ }^{\left.{ }^{*}\right)}$, Melati $^{1)}$, Jumsurizal $^{1)}$ \\ ${ }^{1)}$ Program Studi Teknologi Hasil Perikanan, Fakultas Ilmu Kelautan dan Perikanan, \\ Universitas Maritim Raja Ali Haji, Tanjungpinang, 2911, Indonesia \\ *korespondensi: syarifahnorhayati13@gmail.com
}

Diterima : 06 Oktober 2020; Disetujui : 27 April 2021

\begin{abstract}
The manufacture of bioplastics from kappapycus alvarezii with the addition of extraction of the plant clade, the sea (Scaevola taccada). This study examines the influence of the addition of extracts of the plant clade, the sea and the concentration of carrageenan on physical and mechanical characteristics of bioplastics. The variables studied is the addition of the amount of carrageenan $2 \mathrm{~g}$, $1.5 \mathrm{~g}$, and $1 \mathrm{~g}$ with plant extracts clade, sea $0 \%, 2.5 \%$ and $5 \%$. The results obtained from the manufacture of bioplastics to the thickness of the highest in treatment F1, namely $0.393 \mathrm{~mm}$, for all the thickness of the average range $0.0320-0.393 \mathrm{~mm}$. The level of solubility of the most high are in treatment $F 1$ that is 20,92 minutes, for an average of all the solubility range 12.59-20.92 minutes. The rejection and death of the insects was highest in treatment F3, $7 \%$ and $3 \%$ with the addition of a leaf segmented sea (Scaevola teccada). Thus the addition of the clade, the sea can be said to not meet the Japanesse Industrial Standard (JIS) in the determination of the thickness of the bioplastic that is good that is equal to $\leq 0.25 \mathrm{~mm}$ and also for solubility do not meet the SNI to the water resistance of $99 \%$.
\end{abstract}

Keywords: bioplastics, kappapycus alvarezii, Scaevola taccada

\begin{abstract}
ABSTRAK
Pembuatan bioplastik dari kappapycus alvarezii dengan penambahan ekstraksi tanaman beruas laut (Scaevola taccada). Penelitian ini mengkaji pengaruh penambahan ekstrak tanaman beruas laut dan konsentrasi karagenan terhadap karakteristik fisik dan mekanik bioplastik. Variabel yang diteliti adalah penambahan jumlah karagenan $2 \mathrm{gr}, 1,5 \mathrm{gr}$, dan $1 \mathrm{gr}$ dengan ekstrak tanaman beruas laut $0 \%, 2,5 \%$ dan $5 \%$. Hasil yang didapatkan dari pembuatan bioplastik untuk ketebalan tertinggi terdapat pada perlakuan $\mathrm{F} 1$ yaitu $0,393 \mathrm{~mm}$, untuk semua ketebalan rata-rata berkisar 0,0320-0,393 mm. Tingkat kelarutan paling tinggi terdapat pada perlakuan $\mathrm{F} 1$ yaitu 20,92 menit, untuk rata-rata semua kelarutan berkisar 12,59-20,92 menit. Penolakan dan kematian serangga tertinggi terdapat pada perlakuan F3 yaitu 7\% dan 3\% dengan penambahan daun beruas laut (Scaevola teccada). Dengan demikian penambahan beruas laut ini dapat dikatakan belum memenuhi Japanesse Industrial Standart (JIS) dalam penetapan ketebalan bioplastik yang baik yaitu sebesar $\leq 0,25 \mathrm{~mm}$ dan juga untuk kelarutannya belum memenuhi SNI untuk ketahanan air yaitu $99 \%$.
\end{abstract}

Kata kunci: bioplastik, kappapycus alvarezii, Scaevola taccada

\section{PENDAHULUAN}

Indonesia merupakan negara penyumbang sampah terbesar kedua dunia setelah Cina. Berdasarkan laporan Menteri Lingkungan Hidup dan Kehutanan dalam setahun Indonesia menghasilkan sampah sebanyak 67,8 juta ton dan akan bertambah seiring pertumbuhan jumlah penduduk. Salah satu jenis sampah yang dihasilkan adalah sampah plastik. Sampah plastik merupakan sampah nondegradable, dimana 
sampah plastik berbahan polimer sintetik yang sulit untuk diuraikan oleh mikroorganisme dekomposer di dalam tanah (Utami, 2014). Sulitnya sampah plastik untuk diuraikan oleh mikroorganisme menyebabkan sampah plastik menumpuk dan mencemari lingkungan. Oleh karena itu, diperlukan solusi untuk mengatasi permasalahan ini salah satu solusi yang dapat digunakan yaitu membuat bioplastik.

Bioplastik merupakan plastik yang mudah terurai (biodegradable) oleh mikroorganisme secara alami menjadi senyawa yang ramah lingkungan. Salah satu sumber alam yang dapat digunakan untuk membuat bioplastik adalah rumput laut. Rumput laut merupakan tanaman perairan yang saat ini banyak dibudidayakan oleh masyarakat Indonesia termasuk masyarakat Kepulauan Riau. Rumput laut berdasarkan senyawa kimia yang dikandungnya dapat dikelompokkan menjadi tiga yaitu rumput laut penghasil agar, alginat dan karagenan (Dini et al., 2014).

Berdasarkan pengelompokan rumput laut diatas yang digunakan untuk membuat bioplastik dalam peneilitian ini adalah rumput laut penghasil karagenan. Rumput laut penghasil karagenan adalah rumput laut dari kelompok Rhodopyceae (alga merah). Salah satu jenis rumput laut dari kelompok Rhodopyceae adalah Kappaphycus alvarezii. Rumput laut Kappaphycus alvarezii diketahui mengandung karagenan dimana kandungan karagenanya sebesar 43.3\% (Yanti et al., 2018).

Karagenan merupakan zat aditif alami yang banyak dimanfaatkan dalam berbagai bidang industri makanan dan kosmetika. Karagenan juga dapat digunakan sebagai pembentuk film yang sangat baik dan transparan, dimana karegenan banyak digunakan dalam pembuatan bioplastik, edible film dan sebagai bahan pencampur dalam pembuatan plastik (Pratiwi, 2011). Alasan kareganan dapat digunakan sebagai bahan bioplastik yaitu karena karegenan memiliki sifat sebagai, thickener (bahan pengentalan), stabilizer (penstabil), pembentuk gel, pengemulsi dan lain-lain (Dini et al., 2014).

Karaginan yang dihasilkan dari kappapycus alvarezii dimanfaatkan sebagai emulsifier, gelling, binding agent, thickener, stabilizer, pharmaceutical, kosmetik, formulasi printing dan tekstil (Azevedo et al., 2015; Ajithkumar et al., 2017). Karaginan merupakan polisakarida linier yang terdiri dari 1000 lebih residu galaktosa seperti ester kalium, natrium, dan kalium sulfat dengan galaktosa dan 3,6 anhyrogalaktokopolimer (Heriyanto et al., 2018).

Keuntungan dari menggunakan rumput laut sebagai bahan bioplastik adalah mampu menghasilkan dalam jumlah banyak, harga yang relatif sangat murah, dan bersifat non toksik, serta dapat menghasilkan bioplastik yang menyerupai plastik konvensional (Rajendran et al., 2012).

Tanaman beruwas laut (Scaevola taccada) atau biasa disebut dengan buah pelampung merupakan tanaman yang banyak dijumpai dipesisir pantai. Tanaman ini hidup di tanah pasir berkerikil dan berfungsi sebagai pencegah erosi pantai, berbentuk gundukan bulat, dengan ketinggian mencapai 4 m, (Sutar et al. 2017). Selain itu menurut Manimegalai et al. (2012) ekstrak metanol dari daun beruas laut (S. taccada) menunjukan positif mengandung karbohidrat dan glikosida, benediktus, protein dan asam amino, serta Senyawa fenolik. Senyawa fenolik termasuk salah satu senyawa penting yang tergolong ke dalam senyawa antioksidan alami (Machu et al. 2015). Oleh karena itu dalam penelitian ini akan dilakukan pengujian uji ketebalan, uji kelarutan air, dan uji anti seranggga pada bioplastik. 


\section{METODE PENELITIAN}

\section{Alat dan Bahan}

Alat yang digunakan dalam penelitian ini yaitu : Timbangan analitik, gelas kimia, gelas ukur, aluminium foil, pipet tetes, spatula, pengaduk, termometer, cawan porselen, oven, corong, kertas saring, tissue, magnetik stirer, plat kaca dan jangka sorong digital.

Bahan yang digunakan pada penelitian ini adalah tepung karagenan kappapycus alvarezii, gliserol, daun beruas laut, etanol dan akuades.

\section{Prosedur Penelitian}

Penelitian ini dilakukan dalam 3 tahapan. Tahapan pertama yaitu proses pembuatan bioplastik dengan penambahan beruas laut (Scaevola teccada). Tahap kedua pengamatan karakteristik mekanik bioplastik meliputi ketebalan dan kelarutan terhadap air. Tahap ketiga pengujian anti serangga.

\section{Tahap Ekstraksi Beruas Laut}

Ekstraksi tanaman beruas laut ini digunakan bahan antara lain tanaman beruas laut dan ethanol. Perlakuan bahan sebelum ekstraksi yaitu pelayuan dan pemotongan ukuran bahan untuk membuka kelenjar sampel. Pelayuan dilakukan selama 1x24 jam. Kemudian bahan ditimbang sebanyak 150 gram, perbandingan dari buah dan daun dalam pengekstrakan ini yaitu 1:2. Bahan kemudian dimasukkan dalam larutan etanol dengan perbandingan 1:4 dan dimaserasi selama 3x24 jam kemudian disaring. Hasil penyaringan ditampung dalam gelas kimia dan ditutupi dengan aluminium foil selanjutnya disimpan dilemari pendingin.

\section{Tahap Formulasi Bioplastik}

pembuatan bioplastik ini karagenan yang akan digunakan ditimbang terlebih dahulu sesuai komposisi yang telah ditentukan. Kemudian dilarutkan dengan aquades sebanyak yang diperlukan. kemudian diaduk menggunakan magnetick stirer pada suhu $\pm 60{ }^{\circ} \mathrm{C}$ selama 15 menit. Gliserol kemudian dicampurkan dengan karagenan sebanyak $3 \mathrm{~mL}$ lalu dihomogenkan dengan pemanasan pada suhu $\pm 60{ }^{\circ} \mathrm{C}$ selama 5 menit. Kemudian setelah larutan gliserol dan karagenan sudah homogen, ditambahkan ekstrak buah beruas laut yang telah ditakar sesuai masing-masing perlakuan dan setelah itu diaduk hingga homogen. Setelah larutan homogen kemudian didiamkan selama \pm 5 menit agar terbebas dari gelembung udara dan kemudian dicetak pada plat kaca setelah itu bioplastik dikeringkan dioven selama $1 \times 24$ jam dengan suhu $60^{\circ} \mathrm{C}$ dan kemudian diuji.

\section{Parameter Pengamatan}

Parameter yang akan diamati pada penelitian ini yaitu: uji ketebalan, kelarutan terhadap air dan uji anti serangga.

\section{Analisis Data}

Data yang diperoleh dianalisis sidik ragam untuk mengetahui pengaruh perlakuan. Apabila perlakuan berpengaruh nyata, maka dilanjutkan uji lanjut beda nyata terkecil (BNT) pada taraf uji 5\%.

\section{HASIL DAN PEMBAHASAN}

\section{Uji Ketebalan}

Ketebalan merupakan salah satu parameter penting untuk menentukan tingkat kelayakan suatu bioplastik yang akan digunakan. Ketebalan bioplastik sangat dipengaruhi oleh konsentrasi padatan terlarut pada larutan pembentuk bioplastik. Uji ketebalan dilakukan karena diketahui memiliki hubungan terhadap sifat ketahanan air pada bioplastik, dimana semakin tebal ukuran bioplastik maka ketahanan air pada 
bioplastik juga semakin meningkat (Setiani, 2013). Pengujian ketebalan bioplastik dilakukan dengan menggunakan alat jangka sorong digital dimana nilai ketebalan bioplastik diperoleh dari hasil rata-rata pengukuran yang dilakukan pada lima titik berbeda. Kurniawan (2017) menyatakan bahwa semakin tinggi konsentrasi padatan yang terlarut pada larutan maka film bioplastik yang dihasilkan juga akan semakin tebal. Nilai ketebalan bioplastik dapat dilihat pada Gambar 1.

Berdasarkan Gambar 1. dapat dijelaskan bahwa nilai rata-rata ketebalan bioplastik meningkat seiring dengan bertambahnya konsentrasi karagenan dan berkurangnya konsentrasi beruas laut. Hal ini sesuai dengan pendapat Handito (2011) yang menyatakan bahwa semakin tinggi konsentrasi tepung karaginan yang digunakan, maka akan meningkatkan total bahan padatan terlarut yang ada dalam larutan pembentuk edible film, sehingga setelah proses pengeringan akan menghasilkan edible film yang lebih tebal. Selain itu Ketebalan bioplastik juga sangat dipengaruhi oleh konsentrasi padatan terlarut pada larutan pembentuk bioplastik (Agnes et al. 2018).

Dapat dilihat pada Gambar 1a. Ketebalan bioplastik tertinggi dan terendah diantara buah dan daun beruas laut terdapat pada penambahan buah beruas laut.
Dimana ketebalan tertinggi terdapat pada perlakuan $\mathrm{F} 1$ penambahan buah beruas laut $0 \%$ dan karagenan $2 \%$. Sedangkan ketebalan bioplastik terendah terdapat pada perlakuan F3 penambahan buah beruas laut $5 \%$ dan karagenan $1 \%$.

Nilai rata-rata ketebalan bioplastik dari buah dan daun untuk setiap perlakuan bioplastik dari perlakuan beruas laut $0 \mathrm{ml}$ dan karagenan 2 gram (F1), beruas laut 2,5 $\mathrm{ml}$ dan karagenan 1,5 gram (F2), beruas laut $5 \mathrm{ml}$ dan karagenan 1 gram (F3) yaitu antara $0,0320 \mathrm{~mm}-0,393 \mathrm{~mm}$. Hasil ketebalan yang didapatkan dari bioplastik dengan penambahan buah dan daun beruas laut dan karagenan dapat disimpulkan bahwa belum memenuhi standar Japanesse Industrial Standart (JIS). Hal ini merujuk pada Japanesse Industrial Standart (JIS) dalam penetapan ketebalan bioplastik yang baik yaitu sebesar $\leq 0,25 \mathrm{~mm}$ (Sofia et al., 2016). Tamaela dan Lewerissa (2008) menjelaskan bahwa semakin meningkat konsentrasi bahan akan menyebabkan peningkatan ketebalan plastik.

Berdasarkan hasil dari analisis sidik ragam (ANOVA) menunjukan bahwa nilai ketebalan bioplastik pada setiap perlakuan konsentrasi buah dan daun beruas laut tidak berpengaruh nyata terhadap ketebalan bioplastik berbahan dasar Kappaphycus alvarezii $(\mathrm{P} 0,05)$.

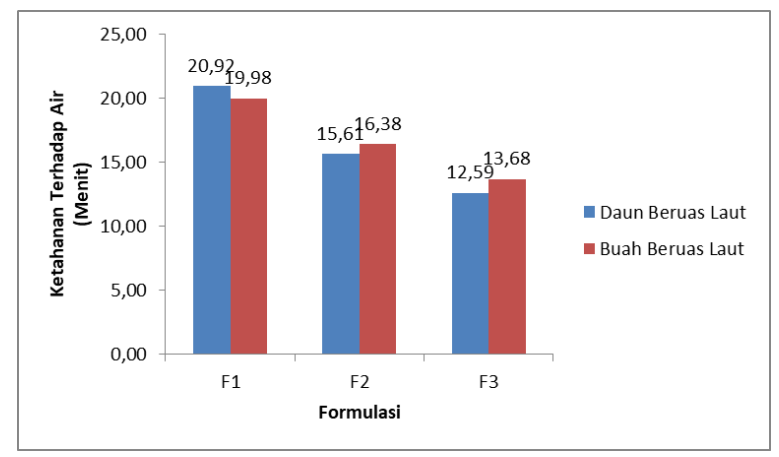

(b)

Gambar 1. Histogram (a) Uji ketebalan bioplastik, (b) Uji kelarutan terhadap air 


\section{Uji Kelarutan terhadap Air}

Uji kelarutan terhadap air merupakan uji yang dilakukan dengan cara melarutkan bioplastik dengan ukuran $3 \times 3 \mathrm{~cm}$ kedalam larutan untuk mengetahui tingkat ketahanan bioplastik terhadap air. Ketahanan air adalah banyaknya air yang diserap oleh bioplastik setelah dicelupkan dalam air. Sifat ketahanan bioplastik terhadap air memiliki hubungan dengan ketebalan bioplastik, dimana semakin tahan bioplastik terhadap air maka dapat dipastikan semakin tebal ukuran bioplstik (Setiani, 2013).

Pengujian ketahanan air suatu bioplastik merupakan salah satu uji yang dilakukan untuk mengukur lama waktu kelarutan suatu bioplastik. Uji kelarutan bioplastik terhadap air dilakukan dengan cara merendam bioplastik kedalam aquades kemudian perhatikan pada menit keberapa bioplastik tersebut larut. Nilai kelarutan bioplastik terhadap air dapat dilihat pada Gambar 1b.

Berdasarkan Gambar tersebut dapat dilihat nilai rata-rata ketahanan air yang diperoleh berbanding lurus dengan nilai ketebalan pada bioplastik. Nilai rata-rata bioplastik dari setiap perlakuan buah dan daun beruas laut $0 \mathrm{ml}$ dan karagenan 2 gram (F1), beruas laut $2,5 \mathrm{ml}$ dan karagenan 1,5 gram (F2), beruas laut $5 \mathrm{ml}$ dan karagenan 1 gram (3) yaitu antara 12,59-20,92 menit. Bioplastik yang memiliki tingkat ketahanan air yang tinggi yaitu bioplastik dengan penambahan daun beruas laut diperlakuan F1 yaitu 20,92 menit. Sedangkan untuk bioplastik yang memilki tingkat ketahanan rendah terdapat pada penambahan daun beruas laut juga yaitu pada perlakuan F3 dengan lama waktu terlarut yaitu 12,59 menit.

Salah satu syarat pentingnya suatu bioplastik yaitu daya larutnya yang rendah. Apabila daya larutnya tinggi dapat menyebabkan bioplastik mudah larut dalam air dan kemampuannya untuk menahan air menjadi berkurang. Kenaikan persentase ketahanan air terjadi seiring bertambahnya konsentrasi karagenan. Hal ini disebabkan karena karagenan merupakan senyawa yang bersifat hidrofobik dan tidak larut dalam air. Menurut Agnes et al (2018) semakin tinggi konsentrasi karaginan maka nilai laju transmisi uap air semakin kecil. Selain itu, ketahanan air juga dipengaruhi oleh adanya gugus - $\mathrm{OH}$ pada plastik yang berasal dari gliserol, ikatan ini menyebabkan bioplastik ini masih memiliki sifat hidrofilik (Utami et al., 2014).

Berdasarakan analisis sidik ragam pembuatan bioplastik dengan penambahan beruas laut dan karagenan berpengaruh nyata terhadap daya kelarutan bioplastik terhadap air. Sehingga dilakukan pengujian lanjut yaitu pengujian BNT dimana pengujian ini dilakuan untuk mengetahui apakah ada persamaan setiap perlakuan bioplastik terhadap daya larutnya. Hasil dari uji BNT dapat disimpulkan bahwa bioplastik dengan perlakuan beruas laut dan karagenan $0 \mathrm{ml}$ daun beruas laut dan karagenan 2 gram (F1), 2,5 ml beruas laut dan karagenan 1,5 gram (F2), $5 \mathrm{ml}$ beruas laut dan karagenan 1 gram (F3) berbeda nyata antara satu dengan yang lainnya. Sedangkan untuk bioplastik dari buah beruas laut yaitu perlakuan F2 sama dengan perlakuan $\mathrm{F} 1$ dan $\mathrm{F} 3$ berpengaruh nyata.

Nilai kelarutan yang tinggi berkaitan dengan sifat biodegradasi film. Di sisi lain, nilai kelarutan yang rendah merupakan salah satu persyaratan penting edible film terutama untuk penggunaan sebagai kemasan pangan yang umumnya memiliki kadar air dan aktivitas air yang tinggi (Singh et al., 2014).

\section{Anti Serangga}

Uji anti serangga merupakan uji yang dilakukan untuk mengetahui pengaruh bioplastik terhadap serangga, dimana serangga yang diuji dalam penelitian ini adalah kutu beras (Sitophilus oryzae). Kutu beras ( $S$. oryzae) adalah salah satu hama yang dapat mengakibatkan kerusakan pada beras. Pengujian ini dilakukan dengan cara 
memasukan kutu beras (S. oryzae) kedalam bioplastik yang sudah diisi dengan beras kemudian dimasukan kedalam toples. Pengamatan dilakukan selama 7 hari dengan memperhatikan apakah kutu beras (S. oryzae) mati atau menolak untuk berada didalam bioplastik.

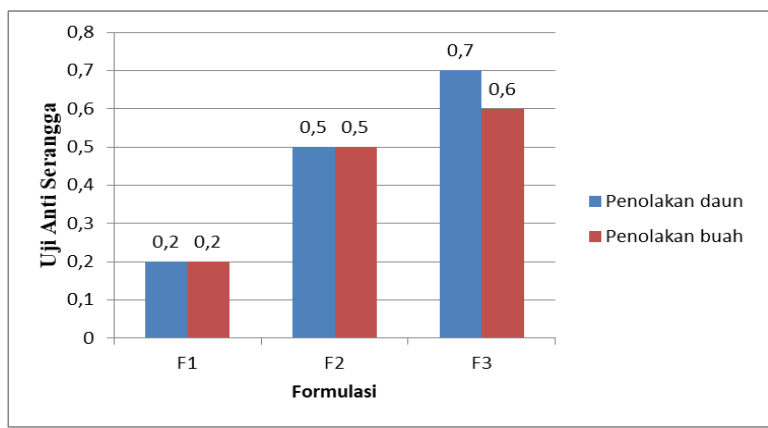

Gambar 3. Uji anti serangga

Berdasarkan Gambar 3. dapat dilihat bahwa persen penolakan kutu beras terendah terdapat pada bioplastik diperlakuan (F1) karena diperlakuan pertama tidak ada penambahan ekstrak dari tanaman beruas laut (Scaevola taccada). Sedangkan dilihat dari perlakuan (F2 dan F3) terjadi penolakan yang disebabkan adanya penambahan ekstrak beruas laut dimana pada ekstrak beruas laut terdapat kandungan senyawa alkaloid, saponin, tanin dan flavanoid (Andi, 2018).

Senyawa alkaloid diketahui bertindak sebagai racun perut dan dapat menganggu sistem kerja saraf pusat serangga. Senyawa saponin memiliki efek gangguan terhadap perkembangan dan gangguan pergantian kulit. Senyawa tanin dapat menghalangi serangga dalam mencerna makanan dan akhirnya mengganggu Senyawa flavonoid yang dapat menyebabkan denaturasi protein sehingga menyebabkan permeabilitas dinding sel dalam saluran pencernaan menurun. Flavonoid juga dapat menimbulkan kelayuan syaraf pada beberapa organ vital serangga yang dapat menyebabkan kematian (Huda, 2018).

Hasil dari penambahan ekstrak daun dan buah beruas laut, penolakan kutu beras tertinggi terjadi pada penambahan daun sebanyak $5 \mathrm{ml}$ (F3) yaitu $0,7 \%$, sedangkan penolakan kutu beras terendah terjadi pada penambahan ekstarak buah dan daun $2,5 \mathrm{ml}$ (F2) yaitu $0,5 \%$. Kematian kutu beras terjadi pada hari ketujuh, dimana kematian tertinggi terjadi pada penambahan daun beruas laut pada perlakuan F3 jumlah kutu beras yang mati sebanyak 3\%. Sedangkan tingkat kematian kutu beras terendah terdapat pada perlakuan F2 penamabahan ekstrak buah beruas laut yaitu sebanyak $0 \%$.

Pembuatan bioplastik dengan penambahan daun dan buah beruas laut tidak berpangaruh nyata terhadap ketebalan bioplastik, tetapi berpengaruh nyata terhadap kelarutan air dan kutu beras yang diuji. Hal ini dikarenakan kurangnya zat padat yang ada pada larutan bioplastik yang dibuat sehingga dapat menyebabkan kurangnya ketebalan yang didapatkan. Selain itu ukuran plat kaca juga berpengaruh terhadap tingkat ketebalan suatu bioplastik.

\section{KESIMPULAN}

pembuatan bioplastik dengan penambahan beruas laut ini dapat dikatakan belum memenuhi standar Japanesse Industrial Standard (JIS) dalam penetapan ketebalan bioplastik yang baik yaitu sebesar $\leq 0,25 \mathrm{~mm}$ dan juga untuk kelarutannya belum memenuhi SNI untuk ketahanan air yaitu $99 \%$.

\section{DAFTAR PUSTAKA}

Azevedo, G., Hilliou, L., Bernardo, G., Sousa-Pinto, I., Adams, R.W., Nilsson, M. \& Villanueva, R.D. 2013. Tailoring Kappa/lota-Hybrid Carrageenan from mastocarpus stellatus with desired gel quality through pre-extraction alkali treatment. Food Hydrocolloids, (31):94-102. 
Agnes, E., M., Septiani, M., dan Wahyuni, K., D. 2018. Karakterisasi Bioplatik dari Karagenan dari Rumput Laut Merah Asal Kabupaten Biak Yang Dibuat Dengan Metode Blending Menggunakan Pelamtis Sorbitol. Jurnal Kimia. 2 (1): 1-8.

Ajithkumar, S., Krishnaraj, G., Abdul Haleem, M.I., Manivasagan, V.Dr., Ramesh Babu, N.G.Dr \& Durai, P.S. 2017. Optimization of Carrageenan Extraction Process from Seaweed. World Journal of Pharmacy and Pharmaceutical Sciences. 6(4):22052213.

Andi, S.,U. 2018. Efektivitas Ekstrak Daun Beruwas Laut (Scaevola Taccada) Terhadap Kadar Sitokin II-10 Pada Mammae Tikus Betina Strain Sprague Dawley Yang Diinduksi Bakteri Staphylococcus Aureus. Tesis Program Studi Magister Kebidanan. Universitas Hasanuddin. Makasar.

Darni, Y., dan Utami, H. 2010. Studi Pembuatan dan Karakteristik sifat Mekanik dan Hidrofobisitas Bioplastik dari Pati Sorgum. 7(4): 88-93.

Dini, F., M. Renardo,. P., A., Achmad, R. 2014. Studi Kinetika Pembentukan Karaginan dari Rumput Laut. Jurnal Teknik Pomits. 3 (1): 27-32.

Handito, D. 2011. Pengaruh Konsentrasi karagenan Terhadap Sifat Fisik dan Mekanik Edible flim. Jurnal Agroteksos. 21 (2): 161-157.

Heriyanto, H., Kustiningsih, I dan Sari, D. K. 2018. The Effect of Temperature and Time of Extraction on the Quality of Semi Refined Carrageenan (SRC). MATEC Web of Conferences.154: 1-6.

Huda, Z. M. 2018. Efektivitas Ekstrak Jeruk Nipis (Citrus aurantifolia) Terhadap Kumbang Beras (Sitopilus sp) dan Kulitas Nasi. Skripsi. Fakultas Tarbiyah dan Keguruan. Universitas Islam Negeri Raden Intan. Lampung.
Kurniawan, d. (2017). Bioplastik Pati Umbi Talas Melalui Proses Melt Intercalation (Kajian Pengaruh Jenis Filler, Konsentrasi Filler dan Jenis Plasticiezer).

Machu, L., Misurcova, L., Ambrozova, J.V., Orsavova, J., Mlcek, J., Sochor, J., Jurikova, T., 2015. Phenolic content and antioxidant capacity in alga food products. Molecules. 20: 1118-1133.

Pratiwi, N. 2011. Optimisasi Ekstraksi Karagenan Kappa Dari Rumput Laut Eucheuma cotonii [Skripsi]. Bogor (ID): Institut Pertanian Bogor.

Rajendran, N., S. Puppala, S.M. Raj, R.B. Angeeleenaa, dan C. Rajam. 2012. Seaweeds can be a New Source for Bioplastics. Journal of Pharmacy Research. Vol. 5 (3) : 1476-1479.

Setiani, W., Sudiarti, T., dan Rahmidar L. 2013. Preparasi dan Karakteristik Edible flim dari Poliblen Pati Sukun Kitosan. Jurnal Valensi 3(2).

Singh, T.P., M.K. Chatli, J. Sahoo. 2014. Development ofChitosan Based Edible Films : Process Optimization Using Response Surface Methodology. Journal of Food Science and Technology. 52 (5) : 2530-2543.

Sutar NG, Kulkarni A, Arangale KB. 2017. Literature review of (Scavola taccada). Journal of Pharmaceutical Research. 5(11): 231-237.

Sofia, I., Murdiningsih, H., Yanti, N. 2016. Pembuatan dan Kajian Sifat-Sifat Fisikokimia, Mekanikal dan Fungsional Edible Film dari Kitosan Udang Windu. Jurnal Bahan Alam Terbarukan. 5 (2).

Tamaela P., dan Lewerissa S. 2008. Karakteristik Edible Film dari Karagenan. Maluku: Fakultas Perikanan dan IImu Kelautan Universitas Pattimura. Jurnal Ichthyos. 7(1): 27-30. 
Utami, RM., Latifah., Widiarti, N. 2014. Yanti, M., Samsu, A., R. 2018. Pertumbuhan Sintesis Plastik Biodegradable dari Kulit Pisang Dengan Penambahan Kitosan dan Plasticizer Gliserol. 3 (2): 56-78.

Dan Kandungan Karaginan Rumput Laut Kappaphycus Alvarezii Pada

Dosis Mikroorganisme Lokal (Mol) Buah Maja. Journal of Blue Oceanic. 2 (1): 1-8. 